\title{
Do human rights issues matter? An empirical analysis of Indonesian companies' reporting
}

\begin{abstract}
$\underline{\text { Abstract }}$
Purpose - This paper examines Indonesian Stock Exchange (IDX) listed companies' human rights disclosures.

Design/methodology/approach - Year-ending 2012 annual report disclosures of 75 IDX listed companies are analyzed. Global Reporting Initiative (GRI) guidelines are employed as the disclosure index checklist.

Findings - The results show a low level of voluntary human rights disclosure (36.74\%). The highest level of communication is for Assessment issues. Very few companies disclosed information about Child labour and forced and compulsory labour. Statistical analysis reveals that board size significantly influences 'human rights' communication in a positive direction. Company size, one of the control variables in this study, is also found to be positively significant. Managerial stakeholder theory partially explains the variability of these disclosures.

Research limitations/implications - The main implication of the findings is that key stakeholders do not see the importance of human rights issues to be disclosed, except for commissioners. It seems that commissioners have the spirit of the United Nation Guiding Principles (UNGPs), requiring companies to respect human rights in daily business operations. Another implication is that companies may attempt to hide certain information regarding child labour and forced and compulsory labour.

Originality/value - This paper provides insights into the disclosure practices of human rights issues in Indonesia. The paper also investigates the key determinants of human rights disclosures, an empirical test which is largely ignored in previous human rights reporting studies. This paper highlights the potency of commissioners in campaigning and promoting the importance of social responsibility on human rights for corporate sustainability.
\end{abstract}

Keywords Human rights disclosures, developing country, Global Reporting Initiative, Indonesia, managerial stakeholder theory

Paper type Research paper

\section{Introduction}

It is widely known that Indonesia is the biggest country in South-East Asia which has been actively participating and contributing its considerable role to regional and global forums such as the East Asia Summit (EAS) and the Group of 20 (G20)(Pakpahan, 2011). According to Pakpahan (2012), Indonesia has coordinated EAS by also including Russia and the USA in this forum's architecture. There is also a big opportunity for Indonesia to communicate and discuss about the Association of Southeast Asian Nations (ASEAN)'s issues with the other G20 members given that Indonesia is the only ASEAN country in 
G20 (see Poole, 2014). Such an opportunity implies Indonesia's important, strategic, and bargaining position as the representative of ASEAN countries within G20.

Indonesia, which is ranked as the fifth most populous nation in the world and is the world's biggest Muslim-majority country, has a significant improvement in the economy in the last couple of years, enjoying annual economic growth rates around 6\%. (Allen, 2013). According to the World Bank's recent report, such an improvement places this country into the $10^{\text {th }}$ largest economy in the world in 2014 (The Jakarta Post, 2014). Some commentators even argue that Indonesia will be the next giant in Asia in the near future (see Allen, 2013). To make this argument become a reality, the new Indonesian president, Joko Widodo, explicitly invited foreign investors in his presentation at the 2014 APEC $^{1}$ CEO Summit to invest in infrastructure projects in Indonesia (Ministry of Finance Republic of Indonesia, 2014).

In spite of Indonesia's 'spectacular' economic growth growing economy and its vital role in the regional and international forums, it appears that there are still complex social problems faced by this developing nation. These problems include human rights issues which may become a barrier for Indonesia to achieve its better 'future'. This country, for instance, still has problems with child labours. According to Director of the Indonesian Directorate General of Training and Productivity ${ }^{2}$, in 2013, there were approximately 300,000 child labours in Indonesia ${ }^{3}$ (Herawati, 2013). There are also discriminations for female workers such as wage discriminations against male workers, sexual abuses, and employee benefit discriminations (Himawan, 2013). Conflicts between companies and local communities also occur in some parts of this developing nation because companies ignore the rights of the indigenous people. In the Province of Central Sulawesi, for instance, there was a conflict between PT Cahaya Manunggal Abadi, a mining company, with the local community because this company planned to do a gold mining exploration on the land owned by the local community (Nugraha, 2013). This company even did not offer share ownerships to the local community, causing the anger of this community. 
In today's business environment, it is arguably important that companies should ensure that the rights of employees and the indigenous people are well fulfilled. Such a fulfillment is parts of companies' corporate social responsibility (CSR) and is critical to be undertaken for the sustainability companies' operations (see Gallhofer, et al., 2011). According to Epstein and Buhovac (2014), global stakeholders currently expect companies to behave in a 'good social manner', including undertaking good human rights-related CSR practices, and to communicate this 'social manner' in certain media such as annual reports. Creditors, for example, will provide funds for companies if these companies undertake good CSR practices such as applying non-discrimination policies to all of their employees. Human rights violation occurring in Indonesia therefore threatens the sustainability of companies and the future of Indonesia's economy.

In Indonesia, all listed companies are required to report any social responsibility activities in their annual reports (BAPEPAM-LK, 2006). Limited companies in and/or related to the area of natural resources, regardless of whether they are listed or not, are also required to undertake social and environmental responsibility activities and communicate these activities in their annual reports under Act No. 40/2007 and Government Regulation No. 47/2012 (Pemerintah Republik Indonesia, 2007; Cahaya et al., 2015). In those regulations, however, there are no specific requirements for companies to disclose human rights - related CSR activities. The Indonesian accounting standards ${ }^{4}$ themselves are completely silent on human rights issues. Disclosures of human rights issues in Indonesia therefore remain voluntary.

There are many past studies examining CSR reporting worldwide, including human rights related CSR reporting (see for example Islam and McPhail, 2011; Sikka, 2011; McPhail and Adams, 2016; Siddiqui and Uddin, 2016). The number of studies looking at human rights disclosures itself is growing, signaling a growing interest in human rights related CSR reporting. Several refereed journals such as Critical Perspectives on Accounting and Accounting, Auditing, and Accountability Journal have even documented human rights related CSR reporting studies into special issue publications. These published human rights accounting studies, however, do not examine the possible determinants of human 
rights disclosures. Islam and McPhail (2011), for instance, explore the extent to which multinational garment retailers invoke the language of human rights when communicating corporate responsibility information. McPhail and Adams (2016) undertake a critical discourse analysis to explore the scope of rights for which corporations are accountable and find that companies' constructions of human rights are broad, ranging from labour rights to the right to health and a clean environment. Siddiqui and Uddin (2016) investigate the state-business nexus in response to human rights violations in the Bangladeshi ready-made garments industry by participating in multiplestakeholder meetings, interviewing participants, and analyzing documentary evidence in newspapers. As these past studies do not examine the possible determinants of human rights disclosures, factors influencing the variability of the extent of labour disclosures have not been documented in the literature. This study therefore attempts to fill this literature gap by examining the extent and the determinants of human rights disclosures in Indonesia Stock Exchange (IDX) listed companies' annual reports.

This study contributes to the existing literature in a variety of ways. Firstly, this study quantitatively examines the possible determinants of a specific subset of CSR reporting namely human rights disclosure. As discussed above, studies on human rights disclosure have been undertaken by previous researchers but they do not investigate the possible predictors of such disclosures. Secondly, this study examines human rights disclosure in Indonesia, a country which, on one side, has an arguably promising economy but, on another side, has complex social problems, including human rights problems. It is therefore expected that this study can provide useful insights regarding disclosures of human rights by companies in this emerging country.

This paper is organized as follows. Section 1 provides an overview of the study, including the purposes and the significance of the study. Section 2 discusses the theoretical framework adopted in the study and develops the hypotheses. The research methodology is presented in Section 3. Section 4 outlines the statistical results, followed by Section 5 which discusses the conclusions of the results.

\section{Theoretical framework and hypotheses development}


Stakeholder theory explains social disclosure practices in terms of the relationship between firms and their stakeholders (Barton et al., 1989). Freeman $(1984,46)$ defines a stakeholder as "any group or individual who can affect or is affected by the achievement of the firm's objectives" (e.g. creditors, employees, customers, suppliers, public interest groups, and governmental bodies). The idea that corporations have stakeholders has become common place in the literature since 1984 (Donaldson and Preston, 1995). As argued by Roberts (1992) and (1985), a good relationship between firms and stakeholders are important for successfully achieving a firms long term objectives.

This theory has two branches, namely an ethical (accountability) branch and a managerial (organization-centered) branch (Deegan, 2009; Gray et al., 1996). The ethical branch of stakeholder theory postulates that all stakeholder groups have a right to be provided with information about how a firm affects them, even if they choose not to use that information, and even if they in turn can not directly affect the firm (Deegan, 2009). This is because, within the stakeholder view, there are implicit contracts between society and corporations in relation to any social activities those corporations have done (Brammer and Pavelin, 2004; Brown and Deegan, 1998). Companies therefore have a responsibility to society to act in their bests interests and to provide them with social disclosures so that they can evaluate the performance of those companies with respect to the social contracts (Henderson et al., 2004).

The managerial branch of stakeholder theory postulates that firms identify important groups of stakeholders and seek to manage each group to benefit the firm (Henderson $e t$ al., 2004). Jones (1999) argues that each group of stakeholders has different interests and the firms should accommodate those interests. One means to manage groups of stakeholders and their interests is through voluntary disclosures (Henderson et al., 2004). A firm, for instance, can voluntarily disclose social information that informs particular groups of stakeholders (e.g. labour union) in the area of operation that is of concern to them (e.g. employees' health and safety issues)(Henderson et al., 2004). 
Stakeholder group identification, which is the main feature of managerial stakeholder theory (Cooper, 2004), is very important for determining a company's future actions. The more important the stakeholder group to the company, the more effort will be exerted in managing the relationship with that group (Gray et al., 1996). In the context of this study, this means that more effort will be exerted by a company in undertaking human rights social activities such as providing training concerning human rights issues to security personnel and disclosing those activities in the annual report. As argued by Roberts (1992), corporate social disclosure has been a relatively successful media for companies to manage their stakeholder relationships.

This paper argues that companies in Indonesia disclose human rights information in order to satisfy important or influential stakeholders. This is because companies have limited resources to undertake human rights - related CSR activities as well as communicate those activities in their annual reports. To be efficient ${ }^{5}$, companies might think to only consider identifying and satisfying influential stakeholders (instead of all stakeholders) as these stakeholders have a greater probability and power in ensuring the 'survival' and the 'sustainability' of companies' operations. To best obtain insights about this possible phenomenon and argument, managerial stakeholder theory is adopted in this study. Accordingly, several independent variables are hypothesized under the umbrella of this theory, as outlined in the following hypotheses development.

\section{Board size}

In Indonesia, boards of commissioners ${ }^{6}$ function as the highest internal control mechanism within companies' corporate governance structure (Bezemer et al., 2014). Commissioners functions as a check balance mechanism to ensure that companies act in the best interest of shareholders and they are responsible for supervising executive directors (Tricker, 1984; Millet-Reyes and Zhao 2010; Bezemer et al., 2014). Due to these positions and authority, commissioners can be categorized as influential stakeholders of companies. Within the framework of managerial stakeholder theory, it can be argued that the relationship between commissioners and the companies must be well managed by 'satisfying' them through, for example, the provision of certain 
information in companies annual reports such as human right information. In the context of human rights disclosures, a company potentially discloses more information when it has a greater number of members in the board of commissioners. This is because each member may be interested in different human rights issues and the company attempts to address all of those issues and then discloses them in its annual reports. In line with past disclosure studies (e.g. Rouf, 2011), this study predicts the following hypothesis:

H1: There is a positive association between board size and the extent of human rights disclosures in annual reports.

\section{Liquidity}

Liquidity reflects the ability of a company to pay its current liabilities (Daniel, 2013). Companies with a higher level of liquidity have more ability to pay its liabilities than companies with a lower level of liquidity do. Information about liquidity is very important for creditors and shareholders to best portray the prospects of companies, particularly about the amount of dividends that will be obtained by shareholders as well as the amount of interests that will be obtained by creditors. The figures of liquidity therefore reflect the power of two influential stakeholders namely shareholders and creditors. When a company has a high level of liquidity, it is arguable that this company potentially discloses more information in their annual reports, including information about human rights issues. This is because such a company has sufficiently financial ability to perform certain activities such as human rights - related CSR activities and discloses those activities. Under the umbrella of managerial stakeholder theory, the purpose of companies with a high level of liquidity to perform certain activities and communicate those activities via certain media is arguably to satisfy shareholders and creditors, as these stakeholder groups are very influential in determining the 'survival' of the companies. Consistent with prior disclosure studies (e.g. Daniel, 2013), the following hypothesis is predicted:

H2: There is a positive association between liquidity and the extent of human rights disclosures in annual reports.

\section{Profitability}


Profitability is a company's ability to make profits (Parker, 1992). Proponents of stakeholder theory such as Purushothaman et al., (2000) argue that companies with a higher level of profitability have more financial support to voluntarily undertake certain CSR activities, including human rights - related CSR activities, and communicate these activities in annual reports. Profitability thus helps companies to undertake certain actions for satisfying identified influential stakeholders. From the perspective of managerial stakeholder theory, it can be argued that a company with a higher level of profitability potentially provides more human rights information in its annual report. Some prior studies such as Robers (1992) document the positively significant impact of profitability on CSR disclosure practices. As such, this study proposes the following hypothesis:

H3: There is a positive association between profitability and the extent of human rights disclosures in annual reports.

\section{Leverage}

The degree of leverage reflect a company's dependence on a key stakeholder group namely creditors. Stakeholder analysis used in previous studies concludes that creditors are important stakeholders whose influences on companies could be managed (Cornell and Shapiro, 1987; Barton et al., 1989). In Indonesia, this stakeholder group is also considered as very important and therefore companies must be transparent to creditors (Okuda and Take, 2005; Komite Nasional Kebijakan Governance, 2006). It is documented in the literature creditors assess companies' CSR activities through CSR disclosures to maintain their confidence in those companies (Roberts, 1992; Purushothaman et al., 2000). Such an assessment potentially occurs in the context of human rights related CSR activities and human rights disclosures. Within the framework of managerial stakeholder theory, it is arguable that companies with a higher degree of leverage potentially disclose more human rights information in their annual reports. Consistent with past disclosure studies (Purushothaman et al., 2000; Alvarez, 2007), this study proposes the following hypothesis:

H4: There is a positive association between leverage and the extent of human rights disclosures in annual reports.

\section{Control variables}


This paper includes company size and industry type as control variables in the statistical analysis. This is because these two variables potentially influence the relationship between the independent and dependent variables in disclosure studies and thus they should be controlled (Eng and Mak, 2003; Haniffa and Cooke, 2005; Kent and Zunker, 2013). Bigger companies potentially disclose more information in their annual reports because they deal with a more variety of issues in their daily activities. Finance companies may disclose less information about social and environmental issues because their employees have lower accident risks during daily operations and such companies do not produce poisonous emissions.

\section{Research methodology}

A sample of 75 Indonesia Stock Exchange (IDX) listed companies is randomly selected from a population of 459 for the year ending 2012 (IDX 2014). Data for all of the variables are collected from the 75 companies' annual reports. Although there is a growing number of Indonesian companies 'publish' stand-alone sustainability reports, disclosures in such reports are not analyzed in this study. This is because, at present, there no regulations in Indonesia requiring companies to produce stand-alone sustainability reports. The number of companies voluntarily publishing stand-alone reports in this nation itself is still small. As stated by Kusumaputra (2012), there are only 40 Indonesian companies 'producing' stand-alone sustainability reports in 2012. The use of annual reports, which is an official reporting media that must be produced by Indonesian listed companies, as the source of the disclosure data in this study is therefore considered appropriate (see Otoritas Jasa Keuangan, 2014).

The dependent variable in this study, which is human rights disclosures, is measured by an unweighted disclosure index. Each disclosure item is therefore deemed equally important (see Meek et al., 1995). A score of 1 (one) is awarded to a sample company when a human right disclosure item is disclosed whereas a score of 0 (zero) is awarded when a human rights disclosure item is disclosed. The final disclosure index for each sample company is calculated by dividing the total score awarded to the sample company with the maximum number of items in the disclosure index checklist. 
Nine Global Reporting Initiative (GRI) human rights disclosure items are adopted as the disclosure index checklist ${ }^{7}$. GRI guidelines are arguably the most widely accepted sustainability guidelines (Albareda, 2013; Epstein and Buhovac, 2014). GRI guidelines themselves are developed and continuously updated through interviews and dialogues with stakeholders around the globe (Global Reporting Initiative, 2014). Prior social and environmental reporting studies in Indonesia have also employed GRI guidelines (e.g. Trisnawati, 2012; Cahaya et al., 2012). Important human rights aspects resulted from conventions or declarations from international bodies such as the 1948 Universal Declaration of Human Rights and the International Labour Organization (ILO) 1998 Declaration are also considered and included in GRI human rights indicators, highlighting the comprehensiveness of these guidelines (Global Reporting Initiative, 2014). The use of GRI human rights indicators as the disclosure index checklist in this study is thus considered appropriate.

The measurement techniques for measuring the independent and control variables are adopted from past studies (e.g. Barako et al., 2006; Huafang and Jianguo, 2007; Bokpin and Isshaq, 2009; Rouf, 2011; Cahaya et al., 2012; Daniel, 2013; Kent and Zunker, 2013). These measurement techniques are displayed in Table I.

\section{[Take in Table I]}

\section{Statistical results}

Results of the descriptive statistics for the independent variables are presented in Table II. It can be seen from the table that board size ranges from 2 to 10 members in the board of commissioners, with a mean of 5 members. There are no specific regulations requiring companies in Indonesia to have a certain number of commissioners in the board. According to Indonesian National Committee of Governance Policy, the number of the commissioners depends on the complexity of a company's business and therefore it is actually up to the company to determine the appropriate number of commissioners in its board (Komite Nasional Kebijakan Governance, 2006). 


\section{[Take in Table II]}

The level of liquidity ranges widely from $20.28 \%$ to $934.46 \%$, with a mean of approximately $202 \%$. Return on assets (ROA) also ranges widely from $-12.75 \%$ to $54.36 \%$ with an average mean of about almost $10 \%$. The figures of ROA highlights that there is an improvement in the economic performance of Indonesian companies during the last decade. As documented in the literature, the average ROA of Indonesian companies has increased from 2\% in 2003 to nearly 4\% in 2007 (see Nurhayati et al., 2006; Cahaya et al., 2012). Such a phenomenon highlights the strength of the Indonesian private sector.

As depicted in Table II, the figure of leverage, which ranges from about $4 \%$ to around $328 \%$ with the mean of almost $52 \%$, shows Indonesian companies' dependence on creditors' contributions. Total assets ranges widely from 3,077 million Rupiah to $111,369,000$ million Rupiah with an average of 7,594,859.46 million Rupiah ${ }^{8} .68 \%$ of sample companies are classified as high profile whereas $32 \%$ of sample companies are categorized as low profile. It can therefore be said that most Indonesian companies operate in a 'sensitive' industry with a possibly greater social impacts on stakeholders.

The descriptive results of the dependent variable are presented in Table III. The descriptive results show that all of the 75 sample companies voluntarily disclose information regarding human rights in their annual reports. The level of human rights disclosures ranges from 11\% (item out of nine disclosure items) to $100 \%$ (all of the nine disclosure items). The mean is $36.74 \%$, showing that, on average, IDX listed companies voluntarily communicate about three human rights disclosure items (out of 9 items) in their annual reports. This finding suggests that the human rights disclosure practices of Indonesia listed companies are low.

[Take in Table III] 
Figure I displays the variation of disclosure levels across the 9 voluntary human rights disclosure items by the 75 sample companies. It can be seen from this figure that Assessment is the most disclosed item (68 companies, 90.67\%). This result indicates that most companies in Indonesia do report number of operations that have been subject to human rights reviews and/or impact assessments. It seems that companies in this developing nation have serious efforts to identify and to assess the possible impacts of their operations on human rights. One possible explanation for this finding is that companies in Indonesia attempt to respond to the United Nation Guiding Principles (UNGPs) which requires corporations worldwide to respect human rights in their daily operations. As reported by The President Post (2014), these principles have been widely accepted in South-east Asia and therefore companies within this region are urged to follow UNGPs by respecting and protecting human rights during their operations as well as remedying any violation of human rights for achieving sustainability (The President Post, 2014).

\section{[Take in Figure I]}

The second most disclosed item is Investment and procurement practices at $70.67 \%$. This suggests that almost $71 \%$ sample companies do have significant investment agreements and contracts incorporating human rights concerns, do have suppliers, contractors, and other business partners that have undergone human rights screening, or do have employee training on policies and procedures concerning aspects of human rights (see Global Reporting Initiative, 2011). The disclosure of Investment and procurement issues indicates that companies in Indonesia attempt to implement the UNGPs for 'remedying' human rights violation they have done. According to Handayani (2014), while companies have an important role in the development and the growth of the Indonesian economy, there are actually a lot of human-rights violations done by companies in this emerging country such as annexations of indigenous people's land in Papua. These violations potentially threaten companies' sustainability. By having investment agreements concerning human rights issues, having business partners that have undergone human 
rights screening, or having employee training in relation to human rights, and by communicating all of these activities in annual reports, companies might believe that their operations will be sustainable.

The third most disclosed item is Security practices at $66.67 \%$. As with the disclosure of Investment and procurement practices, it appears that almost $67 \%$ companies in Indonesia provide training programs which include human rights aspects to their security personnel and communicate these programs in the annual reports. It is arguably important to have such a training to make sure that security personnel can behave professionally while working, by respecting human rights. If there are breaches of laws, rules, and regulations within companies, demonstrations done by employees or the local communities, or thieves caught, for instance, the security personnel is expected to deal with this problem professionally without violence. In practice, such a conduct or professionalism may be difficult to be implemented. Thus, this security practice is incorporated in the security personnel training programs in companies (see Sudahnan, 2011; Dirjen PAUDNI, 2014).

Interestingly, Figure I shows that Child labour and Forced and compulsory labour are the least disclosed items at 4\%. A possible explanation for the small percentage of IDX listed companies communicating these issues is that they do not employ children and there are no forced and compulsory labours in their daily operations. As listed companies are companies which must meet a certain standard required by the capital market, it is logical to assume that such companies tend to be more professional than companies which are not listed on a capital market. Accordingly, they do have professional recruitment systems recruiting working-aged employees with a certain skill. Such recruitment systems are important not only to follow the government's regulation in relation to child labour employment but also for their own future performance. As most of the sample companies do not have child labours and forced and compulsory labours, they may think that it is not necessary to provide information about these issues in their annual reports. 
One could argue that IDX listed companies actually have child labours and/or forced and compulsory labours. This is because data from the Indonesian Directorate General of Training and Productivity shows that there are about 300,000 children working across industries in Indonesia (see again Section 1 of this paper). This argument might have some merit. If this child labour employment really presents, IDX listed companies must have hidden this information from the eyes of their stakeholders and therefore most of those companies do not disclose this fact. However, this might not be totally true. The three hundred thousand child labours do present but they might work in informal employments or are employed by unlisted companies. Data from the US Department of State shows that child labours and forced and compulsory labours are employed in domestic servitude, commercial sexual exploitation, and domestic service (US Department of State, 2014). Further investigation by undertaking qualitative research, however, is needed to prove the truth of this 'speculation'.

Hypotheses 1 to 4 were tested by using multiple regression. Classical assumptions of multiple regression ${ }^{9}$, consisting of normality, multicollinearity, outliers, and homoscedasticity (see Hair et al., 1998; Coakes and Steed, 2007), have been checked and it was found that the homoscedasticity assumption was not initially met. Data of all continuous variables were then transformed into natural logarithm. Heteroscedasticity, however, still existed after the transformation. This study finally decides to use the initial regression results because, according to Tabachnick and Fidell (2001), heteroscedasticity does not invalidate the multiple regression results although the results may become weak. They further argue that the 'violation' of homoscedasticity assumption in the multiple regression analysis is not fatal and as long as the main regression assumption is met, which the normality assumption, the association between variables can be regarded homoscedastic. As the normality assumption is met in the initial regression analysis, the decision to use the initial multiple regression results for testing the hypotheses is considered appropriate. The results of the initial multiple regression analysis are presented in Table IV.

[Take in Table IV] 
As reported in Table IV, the regression model is significant (p-value 0.011). The value of adjusted R-square is 0.141 , meaning that the variability of human rights disclosure practices can be explained by the predictor variables in the model as much as about $14 \%$. Specifically, the variation of voluntary human rights disclosure practices is explained by the variation of board size and company size as their p-values are significant at $5 \%$ level and $10 \%$ level respectively. The coefficient of board size is positive, showing that Hypothesis 1 is accepted. This finding suggests that companies with a greater number of members in the board of commissioners disclose more human rights information in their annual reports. The significance of one control variable namely company size at $10 \%$ moderate significance level and the positive coefficient of this control variable indicates that bigger companies voluntarily provide more human rights information in their annual reports.

\section{Discussion and conclusion}

In summary, there is a low level of human rights disclosure practices (36.74 \%) by IDX listed companies with at least one item is communicated. Most companies probably do not have child labours and forced and compulsory labours and thus only $4 \%$ of sample companies communicate child labour and forced and compulsory labour issues. However, given that there is a small number of companies disclose those human rights issues in the annual reports, there is also a possibility that some companies attempt to hide particular information in relation to child labour and forced and compulsory labour. This is because these issues are sensitive or some of the sample companies may actually implement child labour and forced and compulsory labour employments.

The explanation regarding the small number of companies disclosing child labour issues above is arguable given that there are two possibilities than need further investigations, whether companies do not disclose child labour information because they do not employ child workers or because they actually employ child workers but then they attempt to hide this fact. It is clear from the Manpower Act No. 13/2003 that companies are strictly prohibited to employ children under 13 years old regardless of the hours worked, to employ children ages 13-14 for more than 15 hours per week, and to employ children 
ages 15-17 for more than 40 hours per week (Pemerintah Republik Indonesia, 2003; US Department of State, 2014). The penalty for violating this regulation is two to five years of imprisonment and a fine of 200 million Rupiah to 500 million Rupiah (US Department of State, 2014).

Listed companies might not have child workers as their operations are strictly regulated and monitored by the Indonesian Financial Service Authority (OJK) and they must meet certain criteria or standard to be listed on a capital market. However, given that there are child labour cases in developing countries such as Bangladesh (see Belal, 2008; Islam and Deegan, 2010), there is also a possibility that some IDX listed companies still employ child workers. According to the US Department of State, children in Indonesia are still employed in the following employment: prostitution, mining, pearl diving, construction, scavenging, offshore fishing, cottage industry, production of explosives, domestic service, working on the street, plantations, forestry, and industries that use hazardous chemicals (US Department of State, 2014). Some IDX listed companies categorized in those industries might also be involved child employment. Such a situation may also apply to forced and compulsory labour in this emerging country. To know the truth, further investigations are definitely needed.

An important finding of this study was that board size was a positively significant predictor of voluntary human rights disclosure practices. This is consistent with the result of an empirical study of voluntary disclosure practices in Bangladesh undertaken by Rouf (2011) and supports Hypothesis 2. Companies with a bigger number of commissioners in the board disclose more information about human rights issues in their annual reports. One explanation for this positively significant association is that commissioners are interested in human rights issues and therefore, within the context of managerial stakeholder theory, companies attempt to satisfy them by undertaking good human-rights CSR activities and disclose these activities in the annual reports. Commissioners themselves may have a strong commitment in making sure that corporations they supervise do respect and protect human rights as well as do remedy any violation of human rights. The implication of this finding is that commissioners in Indonesia have the 
UNGPs spirit. Companies can see this spirit and then respond to what they see by reporting human rights information. The other implication is that, to some extent, there is an effective corporate governance association and mechanism between commissioners and the management, particularly in the context of companies' transparency in human rights issues.

Liquidity was found to be insignificant. This finding is consistent with Belkaou-Riahi et al., (1978) and Baroko, et al., (2006). This insignificant statistical result is possibly explained by the argument that shareholders and creditors might be more interested in financial information about companies than human rights issues (see Cahaya et al., 2012) and therefore companies do not provide human rights information for them. This is because shareholders usually need to see the financial performance as well as the dividends they will obtain. Creditors might also be more interested in financial information as it describes companies' financial ability to pay their debts. This argument might also explain the insignificance result of leverage.

This study found that profitability does not significantly influence the level of human rights disclosures. This result is consistent with Hamid (2004) and Kent and Zunker, (2013). A possible explanation for this insignificant result is that companies having satisfactory financial performance do not use their excess money to perform human rights - related CSR activities. Instead, they use the money for enhancing and expanding their businesses for the preparation a more tight competition nationally and internationally (see Indonesia-Investments, 2014). The business enhancement and expansion are possibly done by strengthening their information technology (IT) and information system (IS) infrastructures, opening new branches in Indonesia or overseas, recruiting new experienced manager, etc. In particular, it appears that Indonesian companies use their excess money to increase their competitiveness for dealing with a more tight competition in the ASEAN economic community ${ }^{10}$.

One control variable, which is company size, was found to be positively significant at a moderate statistical level. This positively significant result is consistent with many 
studies showing that bigger companies disclose more information on CSR issues (e.g. Gao et al., 2005; Kent and Zunker, 2013). One possible reason is that larger companies potentially face a more variety of problems in their daily activities as their business scopes and structures are usually more complex. As such, bigger companies do have a more variety of issues to be addressed and disclosed.

The other control variable, which is industry type, was found to be insignificant. Companies in different industries (high and low profiles) may have different CSR disclosure levels but the differences do not exist in specific human rights disclosures. Instead, the differences potentially exist in another CSR disclosure which is arguably more sensitive, which is occupational health and safety disclosures. This is indicated by the extremely high number of work accidents in Indonesia. In 2011, for instance, there were 99,491 reported accidents during works (see Chevny, 2012). Arguably, most of the victims of these accidents are high profile industry workers as more that $60 \%$ of Indonesian workers are employed within high profile industries (see BPS, 2010). Therefore, high profile companies may think that it is much better to address the most urgent CSR issues which are relevant to their industry such as occupational health and safety issues and then they might consider addressing and communicating other CSR issues such as human right issues.

Overall, Indonesian listed companies voluntarily provide a low level of human rights disclosures. It is found that the variability of human rights disclosures is partially explained by managerial stakeholder theory. The low level of human rights disclosures in this developing nation implies that most key stakeholders do not see the importance or the urgency of human rights issues to be disclosed and therefore companies do not attempt to provide information about these issues. It is also implied from the findings that commissioners are the only key stakeholders who expect human rights disclosures from Indonesian companies.

The low level of human rights disclosures may also be explained by the argument that companies do not have child workers and forced and compulsory workers but there is 
also a possibility that companies attempt to hide information regarding these sensitive issues from the eyes of stakeholders. The possible motivation of hiding these issues is that some Indonesian listed companies actually employ children or have forced and compulsory workers and this possibility should be proved by further qualitative investigations. This study provides important contributions to the literature by offering additional knowledge regarding the positively significant impact of board size on the level of human rights disclosure practices in Indonesia and the positively significant influence of one control variable namely company size on the level of those disclosure practices.

Since board size is proven to be the predictor of human rights disclosures, there is a potency to increase the awareness of the business community on human rights issues in Indonesia by utilizing the strategic position and power of commissioners to campaign and promote the importance of human rights related CSR. According to Lukviarman (2016), it is expected that commissioners can help directors formulate companies' strategies. This is because they have various backgrounds and experiences. Thus, to minimize the potential presence of corporate human rights abuses, it is necessary for either national or international human rights organizations (e.g. the National Commission on Human Rights (Komnas HAM), Human Rights Watch, and Human Rights First) to actively approach commissioners in Indonesia and prepare a clear corporate sustainability agenda in relation to human rights issues.

As with all research, this study has limitations. Firstly, this study focuses on a quantitative analysis. The findings, however, needs to be further investigated by undertaking qualitative research so that an in-depth understanding about whether or not companies actually have child workers and forced and compulsory workers can be obtained. Secondly, this study focuses only on disclosures in annual reports. This is because an annual report is an official communication medium that must be provided by listed companies in Indonesia (BAPEPAM-LK, 2006) and is the main company's communication vehicle (Marston and Shrives, 1991; Barako and Brown, 2008). Future human rights - related CSR disclosure studies should therefore undertake further 
investigations through a qualitative examination on the possible reason for the low level of human rights disclosures, particularly on whether or not companies have child workers and forced and compulsory workers. Future studies should also examine disclosures in other communication mediums such as stand-alone sustainability reports if there are a sufficient number of companies 'producing' such reports. 


\section{References}

Albareda, L. (2013), "CSR governance innovation: Standard competition-collaboration dynamic", Corporate Governance, Vol 13 No. 5, pp. 551-568.

Allen, D. (2013), "Indonesia: The next Asian giant", http:/www.itbdigital.com/opinion/2013/03/07/indonesia-the-next-asian-giant/ (accessed 8 July 2013).

Alvarez, A. (2007), "Corporate firm characteristics and human resource disclosure in Spain", In the Thirtieth Annual Congress of the European Accounting Association, Lisbon.

ASEAN. (2008), "ASEAN economic community blueprint", http://www.asean.org/archive/5187-10.pdf (accessed 18 May 2014).

ASEAN. (2013), "ASEAN Comprehensive Investment Agreement (ACIA): A guidebook for businesses and investors", Jakarta: ASEAN Secretariat, http://investasean.asean.org/index.php/ajax/exec_ajax/file_download/824/newsid/ 973/asean-comprehensive-investment-agreement-a-guidebook-for-businessesand-investors.pdf (accessed 27 February 2014).

Bank Mandiri. (2014) "Currency", http://www.bankmandiri.co.id/english/resource/kurs.asp?row=2 (accessed 22 June 2014).

BAPEPAM-LK. (2006), "Salinan keputusan Ketua Badan Pengawas Pasar modal dan Lembaga Keuangan Nomor: kep-134/b1/2006 tentang kewajiban penyampaian laporan tahunan bagi emiten atau perusahaan publik", http://www.bapepam.go.id/pasar_modal/regulasi_pm/peraturan_pm/X/X.K.6.pdf (accessed 24 March 2008).

Barako, D. and Brown, A. M. (2008), "HIV/AIDS disclosures by oil and gas companies", Social and Environmental Accountability Journal, Vol 28 No.1, pp.4-20.

Barako, D., Hancock, G. P. and Izan, H. Y. (2006), "Factors influencing voluntary corporate disclosure by Kenyan companies", Corporate Governance: An International Review, Vol. 14 No. 2, pp. 107-125.

Barton, S., Hill, N. and Sundaram, S. (1989), "An empirical test of stakeholder theory predictions of capital structure", Financial Management, Vol 18 No.1, pp. 36-44.

Belal, A. R. (2008), Corporate social responsibility reporting in developing countries: The case of Bangladesh, Hampshire, Ashgate.

Belkaoui-Riahi, A. and Kahl, A. (1978), Corporate financial disclosure in Canada,Vancouver, Research Monograph of the Canadian Certified General Accountants Association.

Bezemer, P., Peij, L.D.S. and Maassen, G. (2014), "How two-tier boards can be more effective", Corporate Governance Vol. 14 No. 1, pp. 15-31.

Bokpin, G. A. and Isshaq, Z. (2009), "Corporate governance, disclosure and foreign share ownership on the Ghana Stock Exchange", Managerial Auditing Journal Vol. 24 No.7, pp. 688 - 703. Emerald. http://www.emeraldinsight.com (accessed 9 October 2009).

BPS. (2010) http://www.bps.go.id/ (accessed 23 February 2010).

Brammer, S. and Pavelin, S. (2004), "Voluntary social disclosures by large UK companies", Business Ethics: A European Review, Vol.13 No.2/3, pp. 86-99. 
Brown, N. and Deegan, C. (1998), "The public disclosure of environmental performance information -- A dual test of media agenda setting theory and legitimacy theory", Accounting and Business Research, Vol. 29 No.1, pp. 21-41.

Cahaya, F. R., Porter, S., Tower, G. and Brown, A. (2015), "The Indonesian Government's coercive pressure on labour disclosures: Conflicting interests or government ambivalence?", Sustainability Accounting, Management and Policy Journal, Vol. 6 No. 4, pp. 475 - 497.

Cahaya, F. R., Porter, S. A., Tower, G. and. Brown, A. (2012), "Indonesia's low concern for labour issues”, Social Responsibility Journal. Vol. 8 No. 1, pp. 114-132.

Chevny, A. A. (2012) "Keselamatan tenaga kerja: Jamsostek intensifkan pelatihan K3", http://www.bisnis.com/articles/keselamatan-tenaga-kerja-jamsostek-intensifkanpelatihan-k3 (accessed 6 June 2012).

Coakes, S. and Steed, L. (2007), SPSS: Analysis without anguish: Version 14.0 for Windows, Milton, John Wiley \& Sons Australia.

Cooper, S. (2004), Corporate social performance: A stakeholder approach, Aldershot Hants, Ashgate.

Cornell, B. and Shapiro, A. (1987), "Corporate stakeholders and corporate finance", Financial Management, Vol. 16 No.1, pp. 5-14.

Daniel, N. U. (2013), Pengaruh ukuran perusahaan, leverage dan likuiditas terhadap luas pengungkapan laporan keuangan, http://ejournal.unp.ac.id/students/index.php/akt/article/viewFile/65/53 (accessed 27 December 2014).

Deegan, C. (2009), Financial accounting theory, 3rd ed, Sydney, McGraw-Hill.

Dirjen PAUDNI. (2014), NSPK satpam, http://paudni.kemdikbud.go.id/files/ebook/20140207110945/NSPK.Satpam.pdf (accessed 26 December 2014).

Donaldson, T. and Preston, L. (1995), "The stakeholder theory of the corporation: Concepts, evidence, and implications", Academy of Management Review, Vol. 20 No. 1, pp. 65-91.

Eng, L. L. and Mak,Y. T. (2003), "Corporate governance and voluntary disclosure", Journal of Accounting and Public Policy, Vol. 22 No.4, pp. 325-345.

Epstein, M. J. and Buhovac, A. R. (2014) Making sustainability work: Best practices in managing and measuring corporate social, environmental, and economic impacts, 2nd ed., Sheffield, Greenleaf Publishing Limited.

Freeman, R. (1984.), Strategic management: A stakeholder approach, Boston, Pitman.

Gallhofer, S., Haslam, J. and Van der Walt, S. (2011), "Accountability and tranparency in relation to human rights: A critical perspective reflecting upon accounting, corporate responsibility and ways forward in the context of globalisation", Critical Perspectives on Accounting, Vol. 22 No. 8, pp. 765-780.

Gao, S. S., Heravi, S. and Xiao, J. Z. (2005), "Determinants of corporate social and environmental reporting in Hong Kong: A research note", Accounting Forum, Vol. 29 No.2, pp. 233-242.

Global Reporting Initiative. (2011), Sustainability reporting guidelines, Amsterdam, GRI, http://www.globalreporting.org/NR/rdonlyres/53984807-9E9B-4B9F-B5E8-

77667F35CC83/0/G31GuidelinesinclTechnicalProtocolFinal.pdf (accessed 19 May 2011). 
Global Reporting Initiative. (2014), http://www.globalreporting.org (accessed 4 June 2014).

Gray, R., Owen, D. and Adams, C. (1996), Accounting and accountability: Changes and challenges in corporate social and environmental reporting, London, Prentice Hall.

Hair, J. F., Anderson, R. E., Tatham, R. L. and Black, W. C. (1998), Multivariate data analysis, 5th ed, New Jersey, Prentice-Hall.

Hamid, F. (2004), "Corporate social disclosure by banks and finance companies, Malaysian evidence”, Corporate Ownership \& Control, Vol 1 No.4, pp. 118-130.

Handayani, Y. (2014), Korporasi sebagai subyek hukum dalam pelanggaran hak asasi manusia, http://www.gresnews.com/berita/opini/50710-korporasi-sebagai-subyekhukum-dalam-pelanggaran-hak-asasi-manusia/ (accessed 23 December 2014).

Haniffa, R. M. and Cooke. ( 2005), "The impact of culture and governance on corporate social reporting", Journal of Accounting and Public Policy. Vol. 24 No. 5, pp. 391-430.

Henderson, S., Peirson, G. and Harris, K. (2004), Financial accounting theory, Frenchs Forest, Pearson Prentice Hall.

Herawati, Y. (2013), Indonesia berusaha untuk mengakhiri buruh anak, http://khabarsoutheastasia.com/id/articles/apwi/articles/features/2013/06/21/featur e-02 (accessed 20 November 2014).

Himawan, A. (2013), Menjelang May day: Nasib buruh perempuan lebih mengenaskan, https://www.google.com/?gws_rd=ssl\#q=konflik+perusahaan+dan+hak+asasi+wa rga (accessed 30 November 2014).

Huafang, X. and Jianguo. Y. (2007), "Ownership structure, board composition and corporate voluntary disclosure:Evidence from listed companies in China", Managerial Auditing Journal, Vol. 22 No.6, pp. 604 - 619.

Human Resources Development Working Group. (2014), Asia-Pacific economic cooperation, http://hrd.apec.org/index.php/Asia-Pacific_Economic_Cooperation (accessed 23 November 2014).

IAIGlobal. (2016), http://www.iaiglobal.or.id, (accessed 20 March 2016).

IDX. (2014) http://www.idx.co.id/ (accessed 22 June 2014).

Indonesia-Investments. (2014), Masterplan for acceleration and expansion of Indonesia's economic development, http://www.indonesiainvestments.com/projects/government-development-plans/masterplan-foracceleration-and-expansion-of-indonesias-economic-development-mp3ei/item 306 (accessed 22 June 2014).

Islam, M. A. and Deegan, C. (2010), "Media pressures and corporate disclosure of social responsibility performance information: A study of two global clothing and sports retail companies", Accounting and Business Research, Vol. 40 No.2, pp.131-148.

Islam, M. A. and McPhail, K. (2011), "Regulating for corporate human rights abuses: The emergence of corporate reporting on the ILO's human rights standards within the global garment manufacturing and retail industry", Critical Perspectives on Accounting, Vol. 22 No. 8, pp. 790-810.

Jones, M. (1999), "The institutional determinants of social responsibility", Journal of Business Ethics, Vol. 20 No.2, pp. 163-179. 
Kementrian Ketenagakerjaan Republik Indonesia.

(2014), http://www.depnakertrans.go.id/ (accessed 23 December 2014).

Kent, P. and Zunker T. (2013), "Attaining legitimacy by employee information in annual reports", Accounting, Auditing \& Accountability Journal, Vol. 26 No.7, pp. 10721106.

Komite Nasional Kebijakan Governance. (2006), Pedoman umum good corporate governance Indonesia, http://www.bapepam.go.id/pasar_modal/publikasi_pm/info_pm/Pedoman\%20GC G\%20Indonesia\%202006.pdf (accessed 6 July 2008).

Kusumaputra, R. A. (2012), Antam raih penghargaan best website 2012, http://health.kompas.com/read/2012/12/03/21350969/Antam.Raih.Penghargaan.B est.Website.2012 (accessed 6 June 2014).

Lukviarman, N. (2016), Corporate governance : Menuju penguatan konseptual dan implementasi di Indonesia, Solo, Era Adicitra Intermedia.

Marston, C. L. and Shrives, P. J. (1991), "The use of disclosure indices in accounting research: A review article", The British Accounting Review, Vol. 23 No. 3, pp. 195-210. Science Direct.

McPhail, K. and Adams, C. A. (2016) "Corporate respect for human rights: Meaning, scope, and the shifting order of discourse", Accounting, Auditing \& Accountability Journal, Vol. 29 No. 4, pp.650 - 678.

Meek, G. K., Roberts, C. B. and Gray, S. J. (1995), "Factors influencing voluntary annual report disclosures by U.S., U.K. and continental European multinational corporations", Journal of International Business Studies, Vol. 26 No.3, pp. 555572.

Millet-Reyes, B., and Zhao, R. (2010), "A comparison between one-tier and two-tier board structures in France", Journal of International Financial Management and Accounting, Vol. 21 No.3, pp. 279-310.

Ministry of Finance Republic of Indonesia. (2014), President invites investors to invest in Indonesia, http://www.kemenkeu.go.id/en/Berita/president-invites-investorsinvest-indonesia (accessed 23 November 2014).

Nugraha, I. (2013), Kisah perjuangan masyarakat mempertahankan hak, http://www.mongabay.co.id/tag/konflik-warga-dan-perusahaan/ (accessed 30 November 2014).

Nurhayati, R. (2005), The determinants of the level of natural environmental disclosures of JSX listed entities, Master Thesis, Curtin University of Technology.

Nurhayati, R., Brown, A. and Tower, G. (2006) "Understanding the level of natural environmental disclosures by Indonesian listed companies", Journal of the Asia Pacific Centre for Environmental Accountability, Vol. 12 No.3, pp. 4-11.

Okuda, H. and Take, Y. (2005), "Economic reforms and financing structure of Indonesian listed companies after the Asian crisis: Corporate finance issues and the solutions", Japan Bank for International Cooperation Review, Vol 12, pp. 1-31. http://www.jbic.go.jp/english/research/report/review/pdf/report12_1.pdf\#search= $\% 22$ creditor $\% 20$ indonesia $\% 20$ social\%20disclosure $\% 22$ (accessed 21 August 2006).

Otoritas Jasa Keuangan. (2014), http://www.ojk.go.id/ (accessed 27 December 2014). 
Pakpahan, B. (2011), The role of Indonesia in ASEAN, in East Asia Summit and in G20, http://www.thejakartapost.com/news/2011/10/04/the-role-indonesia-asean-eastasia-summit-and-g20.html (accessed 6 September 2012).

Parker, R. H. (1992), MacMillan dictionary of accounting, 2nd ed, London,MacMillan.

Pemerintah Republik Indonesia. (2003), Undang-undang Republik Indonesia nomor 13 tahun 2003 tentang ketenagakerjaan, http://www.nakertrans.go.id/uploads/doc/perundangan/417815068485219144c77b .pdf (accessed 26 January 2009).

Pemerintah Republik Indonesia. (2007) Undang-undang Republik Indonesia nomor 40 tahun 2007 tentang perseroan terbatas, http://www.djkn.depkeu.go.id/download/Peraturan/Undang-Undang/UU402007.pdf (accessed 19 March 2008).

Poole, A. (2014), Indonesia: The voice of developing states?, http://g20watch.edu.au/indonesia-voice-developing-states (accessed 23 November 2014).

Purushothaman, M., Tower, G., Hancock, P. and Taplin, R. (2000), "Determinants of corporate social reporting practices of listed Singapore companies", Pacific Accounting Review, Vol. 12 No. 2, pp. 101-133, Proquest, http://proquest.umi.com (accessed 27 March 2008).

Roberts, R. W. (1992), "Determinants of corporate social responsibility disclosure: An application of stakeholder theory", Accounting, Organizations and Society, Vol. 17 No.6, pp. 595-612.

Rouf, A. (2011), "Corporate characteristics, governance attributes and the extent of voluntary disclosure in Bangladesh", African Journal of Business Management, Vol. 5 No.19, pp. 7836-7845.

Siddiqui, J. and Uddin, S. (2016), "Human rights disasters, corporate accountability and the state: Lessons learned from Rana Plaza", Accounting, Auditing \& Accountability Journal, Vol. 29 No. 4, pp.679-704.

Sikka, P. (2011), "Accounting for human rights: The challenge of globalization and foreign investment agreements", Critical Perspectives on Accounting, Vol. 22 No. 8, pp.811-827.

Sudahnan. (2011) "Kewenangan satpam sebagai tenaga keamanan di perusahaan", Perspektif, Vol. 16 No. 3, pp. 140-148.

Tabachnick, B. G. and Fidell, L. S. (2001), Using multivariate statistics, 4th ed, Boston, Pearson Education Company.

The Jakarta Post. (2014), RI 10th-largest economy: WB, http://www.thejakartapost.com/news/2014/05/05/ri-10th-largest-economywb.html (accessed 21 June 2014).

The President Post. (2014), Indonesia Business Council for Sustainable Development dan ICCO Cooperation memperkuat komitmen bisnis Indonesia terhadap hak asasi manusia, http://thepresidentpostindonesia.com/2014/12/16/indonesia-businesscouncil-for-sustainable-development-dan-icco-cooperation-memperkuatkomitmen-bisnis-indonesiaterhadap-hak-asasi-manusia/ (accessed 21 December 2014). 
Tricker, R. I. (1984), Corporate governance: Practices, procedures and powers in British companies and their boards of directors, Hampshire, Gower Publishing Company.

Trisnawati, R. (2012), "Pengukuran tanggung jawab sosial perusahaan perbankan syariah di Indonesia", Jurnal Akuntansi dan Auditing Indonesia, Vol.16 No. 2, pp. 103121.

Ullman, A. A. (1985), "Data in search of a theory: A critical examination of the relationship among social performance, social disclosure, and economic performance of US firms", Academy of Management Review, Vol. 10 No.3, pp. 540-557.

US Department of State. (2014), Indonesia 2013 human rights report, http://www.state.gov/documents/organization/220408.pdf (accessed 26 December 2014). 


\begin{tabular}{|c|l|}
\multicolumn{2}{|c}{ THE 2011 GLOBAL REPORTING INITIATIVE (GRI) } \\
\multicolumn{1}{|c|}{ HUMAN RIGHTS INDICATORS } \\
\hline No. & \multicolumn{1}{c|}{ Aspect } \\
\hline 1 & Investment and procurement practices \\
\hline 2 & Non-discrimination \\
\hline 3 & Freedom of association and collective bargaining \\
\hline 4 & Child labour \\
\hline 5 & Forced and compulsory labour \\
\hline 6 & Security practices \\
\hline 7 & Indigenous rights \\
\hline 8 & Assessment \\
\hline 9 & Remediation \\
\hline Source: Global & Reporting Initiative (2011). \\
\hline
\end{tabular}


Table I: Measurement Technique of the Independent and Control Variables

\begin{tabular}{|c|c|c|c|}
\hline $\begin{array}{l}\text { Independent } \\
\text { Variables }\end{array}$ & $\begin{array}{c}\text { Control } \\
\text { Variables }\end{array}$ & Measurement & $\begin{array}{l}\text { Type of } \\
\text { Data }\end{array}$ \\
\hline Board Size & & $\begin{array}{l}\text { The number of members in the board of } \\
\text { commissioners }\end{array}$ & Continuous \\
\hline Liquidity & & Current assets divided by current liabilities & Continuous \\
\hline Profitability & & Return on Assets (ROA) : 2 year average & Continuous \\
\hline \multirow[t]{3}{*}{ Leverage } & & Total liabilities divided by total assets & Continuous \\
\hline & $\begin{array}{l}\text { Company } \\
\text { Size }\end{array}$ & Total assets & Continuous \\
\hline & $\begin{array}{l}\text { Industry } \\
\text { Type* }\end{array}$ & $\begin{array}{l}1=\text { high profile } \\
0=\text { low profile industry }\end{array}$ & Categorical \\
\hline
\end{tabular}

Source: Original table

*) Consistent with previous disclosure studies in Indonesia (Nurhayati, 2005; Cahaya et al., 2012), this study classifies seven IDX industry categories, which are Agriculture, Mining, Basic Industry and Chemicals, Miscellaneous Industry, Consumer Goods Industry, Property and Real Estate, and Infrastructure Utilities and Transportation, into high profile industries. This because, in these categories, companies' operations potentially have greater social and environmental impacts on their stakeholders and the natural environment. In contrast, two other IDX industries categories, which are Finance and Trade, Service, and Investment, are classified as low profile industries as the operations of companies in these categories arguably have smaller social and environmental impacts.

Table II: Descriptive Statistics of the Independent and Control Variables

\begin{tabular}{|c|c|c|c|c|}
\hline \multicolumn{5}{|l|}{ Panel A: Continuous Variables } \\
\hline Variable & Minimum & Maximum & Mean & $\begin{array}{l}\text { Standard } \\
\text { Deviation }\end{array}$ \\
\hline $\begin{array}{l}\text { Board size (number of members } \\
\text { in the board) }\end{array}$ & 2 & 10 & 5 & 1.8 \\
\hline Liquidity (\%) & 20.28 & 934.46 & 202.04 & 1.65 \\
\hline Profitability (ROA in \%) & -12.75 & 54.36 & 9.97 & 12.34 \\
\hline Leverage (in \%) & 3.97 & 327.77 & 51.57 & 47.7 \\
\hline Company size (million Rupiah) & 3,077 & $111,369,000$ & $7,594,859.46$ & $15,836,180.33$ \\
\hline \multicolumn{5}{|l|}{ Panel B: Categorical Variable } \\
\hline Variable & & & & Percentage \\
\hline \multicolumn{5}{|l|}{ Industry type } \\
\hline High profile industry & & & & 68 \\
\hline Low profile industry & & & & 32 \\
\hline
\end{tabular}

Source: Original table

Table III: Descriptive Statistics of Human Rights Disclosure Practices

\begin{tabular}{|c|c|c|c|c|}
\hline Dependent Variable & $\begin{array}{c}\text { Minimum } \\
(\%)\end{array}$ & $\begin{array}{c}\text { Maximum } \\
(\%)\end{array}$ & $\begin{array}{c}\text { Mean } \\
(\%)\end{array}$ & $\begin{array}{c}\text { Standard } \\
\text { Deviation } \\
(\%)\end{array}$ \\
\hline
\end{tabular}




\begin{tabular}{|l|c|c|c|c|}
\hline $\begin{array}{l}\text { Human rights disclosure } \\
\text { index (\%) of } 75 \text { sample } \\
\text { companies }\end{array}$ & 11 & 100 & 36.74 & 21.06 \\
\hline
\end{tabular}

Source: Original table

Table IV: Results of Multiple Regression

\begin{tabular}{|l|c|c|c|}
\hline \multicolumn{1}{|c|}{ Variable } & $\begin{array}{c}\text { Predicted } \\
\text { Sign }\end{array}$ & Coefficient & P-value \\
\hline (Constant) & + & 0.126 & 0.126 \\
\hline Board size & + & 0.011 & $0.039^{* *}$ \\
\hline Liquidity & + & 0.298 & 0.488 \\
\hline Profitability & + & 0.009 & 0.125 \\
\hline Leverage & + & 0.00000000289 & 0.855 \\
\hline Company size (control variable) & + & 0.038 & 0.465 \\
\hline Industry type (control variable) & & & 0.141 \\
\hline Model Summary & & 0.19523 & \\
\hline Adjusted R-Square & & $0.011^{* *}$ & \\
\hline Standard Error of the Estimate & \multicolumn{2}{|c|}{} & \\
\hline Regression Model (Sig.) & & & \\
\hline
\end{tabular}

**significant at $5 \%$ level; * significant at $10 \%$ percent level

Source: Original table 
Figure I: The 9 Items of Voluntary Human Rights Disclosures

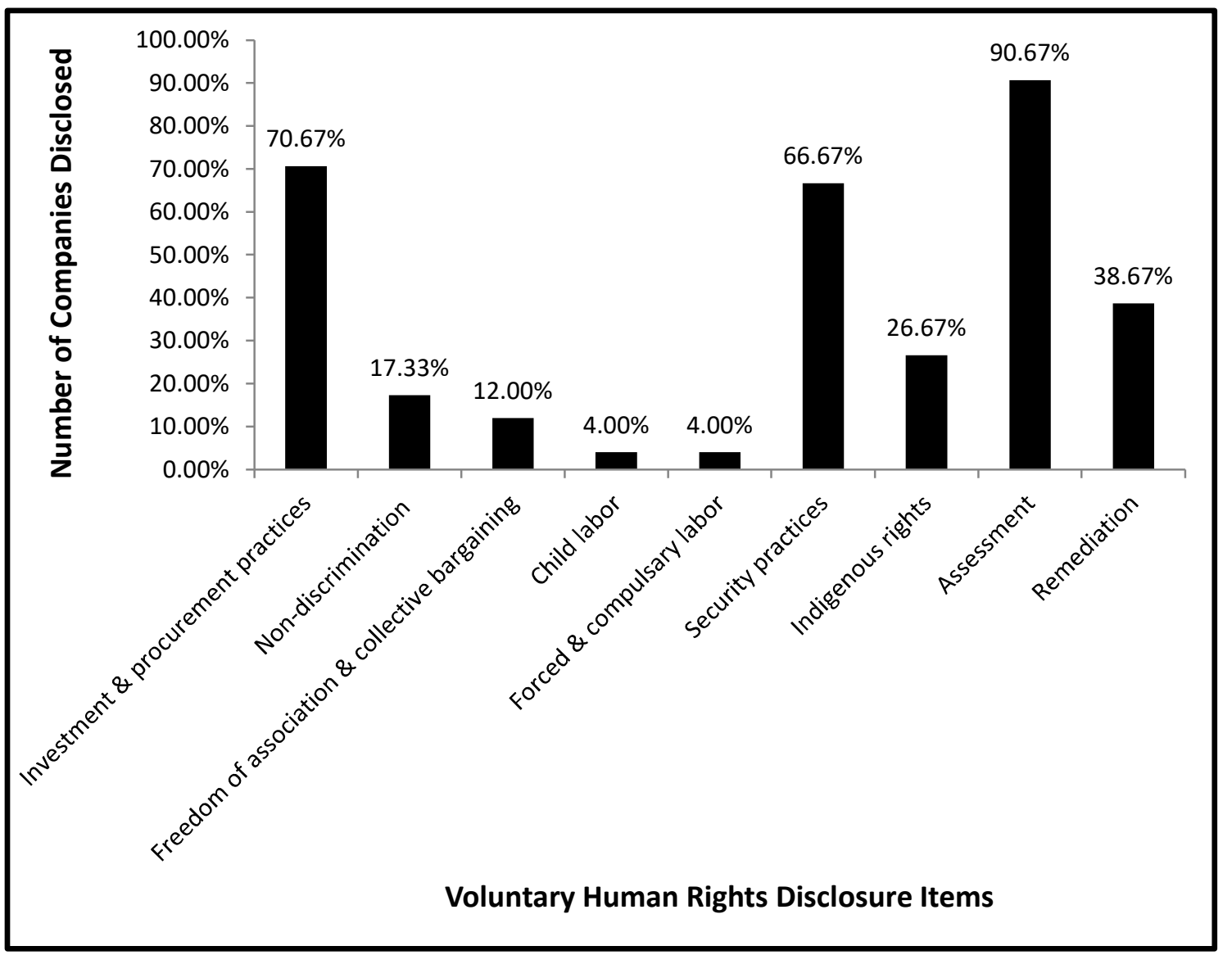

Source: Original figure

\footnotetext{
Notes

${ }^{1}$ The Asia-Pacific Economic Cooperation (APEC) is a forum for facilitating economic growth, cooperation, trade and investment in the Asia-Pacific region and currently has 21 member states such as Japan, Malaysia and New Zealand (Human Resources Development Working Group, 2014). The latest APEC Summit was held from 8 to 9 November 2014 in Beijing, China (Ministry of Finance Republic of Indonesia, 2014).

${ }^{2}$ Directorate General of Training and Productivity is a directorate general under the Ministry of Employment, the Republic of Indonesia (Kementrian Ketenagakerjaan Republik Indonesia, 2014).

${ }^{3}$ Under Act No. 13/2013, companies in Indonesia are not allowed to employ children under 13 years old (Pemerintah Republik Indonesia, 2013).

${ }^{4}$ At present, Indonesia is in the process of convergence with the international accounting standards (IAIGlobal, 2016).

5 As stated by Epstein and Buhovac (2014), corporations need financial resources to undertake various sustainability activities, including human rights protection programs, and disclose those activities in a certain medium such an annual report. Each corporation's financial resources themselves are always limited. To be efficient in the use of financial resources, only stakeholders which are considered influential are managed and satisfied by companies. Arguably, it is impossible to satisfy all stakeholders due to the limited amount of corporations' financial resources.

${ }^{6}$ In Indonesia, companies apply a two tier management structure in which commissioners can be regarded as equivalent to directors in a one tier management structure (Pemerintah Republik Indonesia, 2007). Commissioners in a two tier structure and directors in a one tier structure has the same responsibility as the supervisors and the advisors of the management (Bezemer et al., 2014).

7 The details of the nine GRI human rights items used as the disclosure index checklist in this study are presented in the appendix. The GRI version adopted in this study is the 2011 version, which is termed as G3.1
} 
(see Global Reporting Initiative, 2011). This is because the version which is relevant to the 2012 data is the 2011 version.

${ }^{8}$ For illustrative purposes, 7,594,859.46 million Rupiah equals to about 605 million US Dollars. This currency conversion is calculated based on the recent value of Rupiah (December 20, 2014) against the US Dollar (see Bank Mandiri, 2014).

${ }^{9}$ For brevity, the results of the assumption tests are not shown in this paper.

10 The ASEAN Economic Community is the goal of regional economic integration resulted from the joint commitment by leaders of ASEAN members in the 12th ASEAN Summit and should be established by 2015 (ASEAN, 2008). In such a community, ASEAN will become a region with free movement of skilled labours, goods and services, investment, and freer flow of capital (ASEAN, 2013). 